\title{
Erratum to: Ground movement mechanism in tectonic stress metal mines with steep structure planes
}

XIA Kai-zong(夏开宗), CHEN Cong-xin(陈从新), LIU Xiu-min(刘秀敏), ZHENG Yun(郑元), FU Hua(付华)

State Key Laboratory of Geomechanics and Geotechnical Engineering, Institute of Rock and Soil Mechanics, Chinese Academy of Sciences, Wuhan 430071, China

(C) Central South University Press and Springer-Verlag GmbH Germany, part of Springer Nature 2017

Erratum to: J. Cent. South Univ. (2017) 24: 2092-2104

DOI: https://doi.org/10.1007/s11771-017-3618-2

The original version of this article unfortunately contained a mistake. The corrected author list is given below:

XIA Kai-zong(夏开宗), CHEN Cong-xin(陈从新), LIU Xiu-min(刘秀敏), ZHENG Yun(郑允), FU Hua(付华)

The online version of the original article can be found at https://doi.org/10.1007/s11771-017-3618-2

Corresponding author: XIA Kai-zong, PhD Candidate; Tel: +86-18271825180; E-mail: xiakaizong1988@sina.com 